\title{
Sárasogsmeðferð á Íslandi - notkun og árangur
}

Ingibjörg Guðmundsdóttir ${ }^{1}$ húkrunarfræðingur, Steinn Steingrímsson² læknir, Tómas Guðbjartsson²,3 læknir

\section{ÁGRIP}

Inngangur: Sárasogsmeðferð (negative pressure wound therapy, NPWT) er nýjung í sárameðferð par sem undirprýstingur er myndaður staðbundið í sárbeðnum með loftpéttum umbúðum og sogtæki. Tilgangur rannsóknarinnar var að kanna ábendingar og árangur sárasogsmeðferðar hjá heilli pjóð, en slík rannsókn hefur ekki verið gerð áđur.

Efniviður og aðferðir: Afturskyggn rannsókn sem náði til allra sjúklinga, bæði á sjúkrahúsum og utan, sem fengu sárasogsmeðferð á Íslandi frá janúar til desember 2008. Ábending, tímalengd og árangur meðferðar voru skráð úr sjúkraskrám. Einnig var metinn gróandi sára og pættir sem geta haft áhrif á gróanda, eins og sykursýki, reykingar og aldur. Niðurstöður: Alls fengu 56 sjúklingar 65 sárasogsmeðferðir. Karlar voru 63\% og meðalaldur 62 ár (bil 8-93 ár). Meðferð var veitt á sjúkra- húsi i 85\% tilfella, oftast á æða- og brjóstholsskurðdeildum. Algengustu ábendingar fyrir meðferð voru sýking í sári (40\%), örvun gróanda (42\%) og viðhald opinna holrúma (19\%). Flest sárin voru á neðri útlimum (26\%) og brjóstkassa (25\%). Sex sjúklingar létust vegna undirliggjandi sjúkdóma og voru peir ekki teknir með við mat á gróanda sára. Af 59 meðferðum náđist fullur gróandi sára í 40 (68\%) en ófullkominn gróandi í 19 (32\%). Fylgikvillar tengdir meðferð voru skráðir í 19 (32\%) tilfellum og voru verkir (12\%) og húðvandamál (11\%) algengust.

Ályktanir: Sárasogsmeðferð er töluvert notuð á Íslandi, sérstaklega við sýkt skurðsár og langvinn sár. Í tveimur priðju tilfella náđist fullur gróandi sára sem telst góður árangur.
${ }^{1}$ ÆEðaskurðdeild, ${ }^{2}$ hjarta- og lungnaskurðdeild Landspítala, ${ }^{3} æ k$ nadeild Háskóla Íslands.

Fyrirspurnir Tómas Guðbjartsson tomasgud@landspitali.is

Greinin barst: 1. september 2011 sampykkt til birtingar: 10. janúar 2012.

\section{Inngangur}

Sárasogsmeðferð (negative pressure wound therapy, NPWT) byggir á pví að undirprýstingur er myndaður í sárbeðnum með lokuðum umbúðum og sárasugu. Meðferðinni var fyrst lýst árið 1997 og hefur síðan náð mikilli útbreiðslu, meðal annars hér á landi. ${ }^{1}$ Vessi er fjarlægður úr sárinu með undirbrýstingi sem veldur auk pess togi á frumur í sárbeðnum. Togið örvar bæði myndun vaxtarpátta sem hvetja til nýmyndunar æða og frumuskiptingar í sárinu sem flýtir fyrir gróningu pess. ${ }^{1,2}$ Einnig minnkar yfirborð sársins par sem sogið dregur sárkantana saman og bakteríum í sárinu fækkar par sem undirprýstingur heftir vöxt peirra. ${ }^{3}$

Sárasogsumbúðir eru tvenns konar, svampar eða grisjur sem eru lokaðar af í sárinu með punnri plastfilmu. Algengast er að nota polyurethan svamp með 400-600 ㅆm stórum götum til að jafna undirprýstinginn í sárinu. ${ }^{1}$ Við sárasogsmeðferð er oftast beitt stöðugum undirprýstingi á bilinu -75 til $-125 \mathrm{mmHg}$ og er notað til pess sérstakt sárasog sem tengt er við umbúðirnar með slöngu. ${ }^{4}$ Við sum sár er pó mælt með pví gera hlé á soginu, til dæmis í tvær mínútur eftir 5 mínútna sog. ${ }^{1,2}$

Sárasogsmeðferð er hægt að nota á flestar tegundir sára og fjölmargar rannsóknir hafa sýnt fram á góðan árangur. Petta á sérstaklega við um sýkt skurðsár og sykursýkissár, ${ }^{5-7}$ sem jafnframt eru algengustu ábendingar fyrir sárasogsmeðferð, auk bráðasára. ${ }^{2,}$ 5-9 Hins vegar er ekki mælt með meðferðinni á blæðandi sár eða sár yfir óvörðum viðkvæmum líffærum..$^{9-11}$ Meðferðin er kostnaðarsöm en rannsóknir hafa sýnt að kostnaður jafnast út par sem sárgræðsla er hraðari en við hefðbundna sárameðferð og í mörgum peirra er legutími styttri. ${ }^{6,8}$
Sárasogsmeðferð hefur verið beitt á Íslandi í nokkur ár og hefur notkun aukist stöðugt. Upplýsingar hefur vantað um ábendingar og árangur meðferðarinnar hér á landi, og á pað við um stofnanir, einstakar deildir og sérgreinar. Tilgangur pessarar rannsóknar var að kanna hversu margir fengu sárasogsmeðferð á Íslandi á einu ári, bæði innan og utan sjúkrahúsa, og jafnframt að leggja mat á ábendingar og árangur meðferðarinnar.

\section{Efniviður og aðferðir}

Rannsóknin var afturskyggn og náði til allra sjúklinga á Íslandi sem fengu sárasogsmeðferð frá 1. janúar til 31. desember árið 2008. Í flestum tilvikum var um sjúklinga að ræða sem fengu meðferð á Landspítala en nokkrir fengu meðferð á Sjúkrahúsinu á Akureyri. Á Landspítala við Hringbraut var leitað að sjúklingum eftir aðgerðanúmerum en par hafa allar sárasogsmeðferðir verið skráðar í rafræna aðgerðaskrá. Á Landspítala í Fossvogi var sárasogsmeðferð ekki alltaf skráð í rafræna aðgerðaskrá, enda í mörgum tilfellum veitt á legudeildum, oftast lýtalækningadeild og æðaskurðdeild. Pví var fenginn listi frá upplýsingatæknideild Landspítala yfir alla sjúklinga sem lágu á pessum deildum árið 2008. Farið var yfir sjúkraskrár peirra og leitað sérstaklega að sjúklingum sem fengu sárasogsmeðferð. Einnig var haft samband við lækna og hjúkrunarfræðinga á öðrum deildum og sviðum Landspítala og kannað hvort sárasogsmeðferð hefði verið notuð á peirra deildum. Á Sjúkrahúsinu á Akureyri voru allir sjúklingar sem höfðu fengið sárasogsmeðferð skráðir sérstaklega af hjúkrunarfræðingi á sáramóttöku og út 
Tafla I. Skipting og tímalengd sárasogsmeðferða eftir sérgreinum.

\begin{tabular}{lcccc} 
Sérgrein & $\mathrm{n}$ & $\begin{array}{c}\text { Fjöldi } \\
\text { með- } \\
\text { ferða }\end{array}$ & $\begin{array}{c}\text { Heildar- } \\
\text { fjöldi daga í } \\
\text { meðferð }\end{array}$ & $\begin{array}{c}\text { Meðallengd } \\
\text { meðferðar, } \\
\text { dagar }\end{array}$ \\
\hline ÆEðaskurðlækningar & 18 & 23 & 447 & 19 \\
\hline Brjóstholsskurðlækningar & 17 & 17 & 233 & 14 \\
\hline Lýtalækningar & 12 & 13 & 408 & 31 \\
\hline Bæklunarlækningar & 4 & 5 & 153 & 31 \\
\hline Endurhæfingalækningar & 1 & 1 & 17 & 17 \\
\hline Almennar skurðlækningar & 4 & 4 & 98 & 25 \\
\hline Smitsjúkdómalækningar & 1 & 2 & 237 & 119 \\
\hline Samtals & $57^{*}$ & 65 & 1593 & 25 \\
\hline
\end{tabular}

*Einn sjúklingur er tvítalinn par sem hann var með̌höndlađur á tveimur sérgreinadeildum vegna óskyldra vandamála.

frá peirri skrá var hægt að finna sjúkraskrár peirra. Einnig var haft samband við umboðsaðila sárasogstækja á Íslandi og fengnar upplýsingar um sjúklinga sem höfðu verið meðhöndlaðir utan spítala.

\section{Framkvæmd sárasogsmeðferðar}

Sárasogsmeðferð fer pannig fram að áður en umbúðir eru lagðar eru sárin hreinsuð og dauður vefur fjarlægður. Ef notast er við svampumbúðir er svampurinn sniðinn ofan í sárið og plastfilma límd yfir. Filman er látin ná út á húðbarmana pannig að ekki leki loft meðfram henni og pannig myndað lofttæmi. Síðan er gert lítið gat á filmuna og slanga úr sárasugunni tengd við svampinn. Pegar notast er við grisjur er sogslöngu úr sogtækinu komið fyrir á milli grisjulaga og filma límd yfir grisjurnar. Sáravökvi er sogaður úr sárinu í sérstakt safnhólf á sogtækinu sem hægt er að skipta um án pess að skipta um umbúðir á sárinu sjálfu. Oftast er skipt um umbúðir annan til priðja hvern dag en fyrir ákveðnar tegundir sára eru umbúðir pó hafðar á í allt að 5 daga, til dæmis við miðmætissýkingar eftir opnar hjartaskurðaðgerðir. ${ }^{12}$

Skráðar breytur

Tafla II. Tegundir sára hjá sjúklingum sem fengu sárasogsmeðferð á Íslandi árið 2008, fjöldi (\%).

\begin{tabular}{lcc} 
Tegund & 13 & $(20)$ \\
\hline Langvinn fótasár & 9 & $(14)$ \\
\hline Sýkt skurðsár (önnur en bringubeinsskurðir) & 9 & $(14)$ \\
\hline Bringubeinsskurður, sýktur & 9 & $(14)$ \\
\hline Prýstingssár & 8 & $(12)$ \\
\hline Tábeður sem greri ekki eftir aflimun & 6 & $(9)$ \\
\hline Bringubeinsskurður, ósýktur & 3 & $(5)$ \\
\hline Opinn holskurður, vegna blæðingar í kviðarholi & 2 & $(3)$ \\
\hline Felliskurður á útlim vegna hólfaheilkennis (compartment syndrome) & 2 & $(3)$ \\
\hline Fistill & 1 & $(2)$ \\
\hline Brunasár & 1 & $(2)$ \\
\hline Til stuðnings húðágræðslu & 1 & $(2)$ \\
\hline Stúfur sem ekki greri eftir aflimun & 1 & $(2)$ \\
\hline Kviðarhols-hólfaheilkenni (abdominal compartment syndrome) & 65 & $(100)$ \\
\hline Samtals & 2 & \\
\hline & 2 & 1 \\
\hline
\end{tabular}

Tafla III. Ábendingar fyrir sárasogsmeđferð á Íslandi árið 2008 og hlutfall sjúklinga par sem sár greru að fullu, fjöldi (\%).

\begin{tabular}{llccc} 
Ábending fyrir meðferð & \multicolumn{2}{c}{ Fullur gróandi } & \multicolumn{2}{c}{ Ófullnægjandi gróandi } \\
Sýkt sár $(\mathrm{n}=26)$ & 18 & $(69)$ & 8 & $(31)$ \\
\hline Örva gróanda $(\mathrm{n}=27)$ & 16 & $(59$ & 11 & $(41)$ \\
\hline Halda holrúmum opnum $(\mathrm{n}=6)$ & 6 & $(100)$ & 0 & $(0)$ \\
\hline Samtals & 40 & & 19 &
\end{tabular}

Úr sjúkraskrám voru skráðar eftirfarandi breytur: kyn, aldur, hæð, pyngd, reykingasaga, tegund og staðsetning sára og undirliggjandi orsakir, tímalengd meðferðar, árangur og fylgikvillar. Einnig voru skráðir undirliggjandi sjúkdómar sem geta haft áhrif á gróanda sárs. Öllum sjúklingum var fylgt eftir miðað við lifun í pjóðskrá. Pannig fengust upplýsingar um hvort sjúklingar voru látnir eða á lífi pann 1. nóvember 2009. Meðaleftirfylgd var 13,6 \pm 6,6 mánuðir (bil 0-22).

\section{Mat á árangri og undirliggjandi sjúkdómum}

Við mat á árangri sárasogsmeðferðar var kannað hvernig sárið greri með upplýsingum úr sjúkraskrám, alveg fram að útskrift eða par til meðferð á göngudeild lauk. Рað var skilgreint sem fullur gróandi ef hægt var að loka sári í skurðaðgerð, gera húðágræðslu eða gróandi var pað mikill að ekki var lengur pörf á sárasogsmeðferð.

Skráðir voru fylgikvillar meðferðar úr sjúkraskrám og var aðallega stuðst við hjúkrunarskýrslur og dagála lækna.

\section{Tölfræði}

Við tölfræðilega úrvinnslu gagna var notast við forritið SPSS ${ }^{\circledast}$ (útgáfa 17.0). Notuð var lýsandi tölfræði fyrir tíðni, hlutföll, miðgildi, meðaltöl og staðalfrávik. Kí-kvaðrat, Fischer's Exact eða tpróf voru notuð við samanburð hópa. Heildarlifun var metin með aðferð Kaplan-Meier. Marktæknimörk miðuðust við p-gildi <0,05.

Leyfi

Áður en rannsóknin hófst voru fengin leyfi hjá Vísindasiðanefnd, Persónuvernd og lækningaforstjórum Landspítala og Sjúkrahússins á Akureyri. Ekki purfti upplýst sampykki sjúklinga um aðgang að sjúkraskrá peirra par sem sjúklingarnir höfðu allir lokið meðferð og upplýsingar sem safnað var voru ekki persónugreinanlegar.

\section{Niðurstöður}

Árið 2008 voru veittar 65 sárasogsmeðferðir á Íslandi hjá 56 sjúklingum, 35 (63\%) körlum og 21 (38\%) konu. Meðalaldur sjúklinganna var 62 ár (bil 8-93). Alls fengu 8 sjúklingar (14\%) sárasogsmeðferð oftar en einu sinni á rannsóknartímabilinu og var oftast um endurtekna meðferð að ræða á sama sári. Einn sjúklingur fékk meðferð prisvar sinnum og annar á tveimur sérgreinadeildum með nokkurra mánaða millibili vegna óskyldra vandamála.

Sárasogsmeðferð var í flestum tilvikum veitt á sjúkrahúsi, eða í 55 (85\%) tilvikum, 48 á Landspítala og 7 á Sjúkrahúsinu á Akureyri. Í 5 tilvikum fór meðferð fram bæði heima og á sjúkrahúsi (8\%). 


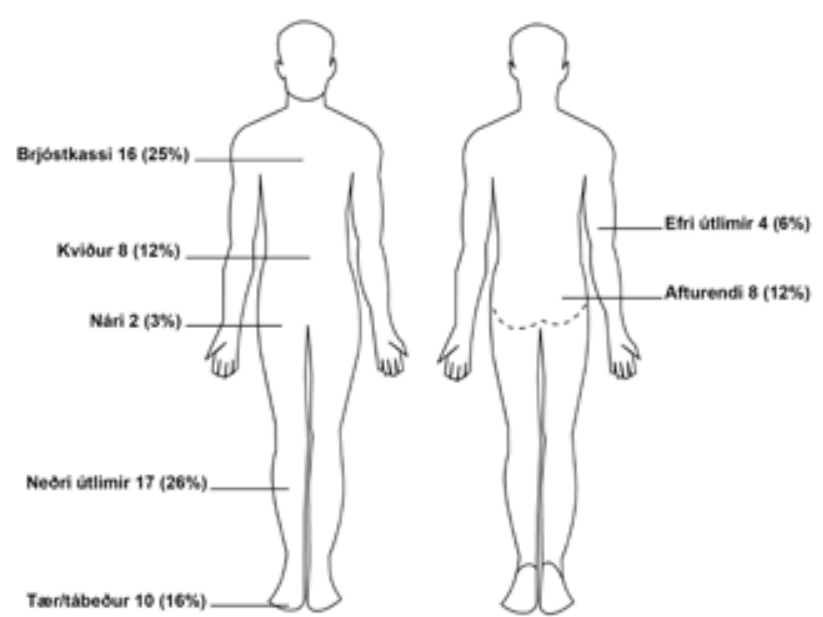

Mynd 1. Staðsetning sára hjá sjúklingum sem fengu sárasogsmeðferða á Íslandi árið 2008, fjöldi meðferða (\%). Mynd: Ingibjörg Guðmundsdóttir.

Í töflu I er sýnd skipting milli sérgreina, bæði eftir fjölda sjúklinga en einnig fjölda sárasogsmeðferða. Einnig er tiltekin tímalengd meðferðar. Flestar meðferðir voru veittar á æðaskurðadeild, eða 23 meðferðir, og 17 á brjóstholsskurðdeild par sem meðferðardagar voru fæstir, en hver meðferð tók að meðaltali 14 daga.

Ábendingar fyrir sárasogsmeðferð voru aðallega prenns konar. Algengust var örvun gróanda í 27 (42\%) tilvikum, meðferð sýktra sára í 26 meðferðum (40\%) og í 12 (19\%) tilvikum til að halda holrúmum opnum, til dæmis eftir stórar kviðar- eða brjóstholsaðgerðir. Í töflu II má sjá nánari útlistun á tegundum sára sem meðhöndluð voru, en sýkt skurðsár voru algengust (28\%) og var helmingur peirra í sýktum bringubeinsskurði, næst komu langvinn fótasár (20\%) og síðan prýstingssár (14\%).

Á mynd 1 sést staðsetning sára sem meðhöndluð voru með sárasogsmeðferð. Flest sáranna voru staðsett á neðri útlimum (26\%) og aðeins færri á brjóstkassa (25\%).

Í öllum tilvikum nema einu var notast við svampumbúðir (98\%). Oftast var notast við sárasugu frá $\mathrm{KCI}^{\circledR}$, eða í 47 tilvika (72\%), og veggsog án sérhæfðs sárasogstækis í 13 tilvikum (20\%).

Tafla IV. Samanburður á árangri sárasogsmeðferðar eftir gróanda sára. Gefinn er upp fjöldi (\%),en meðaltal aldurs og líkamspyngdarstuðuls.

\begin{tabular}{lccc} 
Pættir & $\begin{array}{c}\text { Fullur gróandi } \\
(\mathrm{n}=40)\end{array}$ & $\begin{array}{c}\text { Ófullkominn } \\
\text { gróandi }(\mathrm{n}=19)\end{array}$ & p-gildi \\
\hline Meðalaldur (ár) & 58 & 68 & 0,04 \\
\hline Karlkyn & $24(60)$ & $13(68)$ & 0,58 \\
\hline Líkamspyngdarstuðull $\left(\mathrm{kg} / \mathrm{m}^{2}\right)$ & 28 & 27 & 0,59 \\
\hline Saga um reykingar & $8(20)$ & $3(16)$ & 0,71 \\
\hline Útæðasjúkdómur & $17(43)$ & $13(68)$ & 0,10 \\
\hline Sykursýki & $10(25)$ & $11(58)$ & 0,02 \\
\hline Mænuskaði & $5(13)$ & $2(11)$ & $\ddagger$ \\
\hline Bláæðasjúkdómar & $3(8)$ & $4(21)$ & $\ddagger$ \\
\hline Sterameðferð & $2(5)$ & 0 & $\ddagger$ \\
\hline Geislameðferð & $2(5)$ & $1(5)$ & $\ddagger$
\end{tabular}

$\ddagger$ = einstaklingar of fáir fyrir tölfræðilegan samanburð

Sjúklingar gátu haft fleiri en einn undirliggjandi sjúkdóm, en í 16 tilvikum vantaði

upplýsingar um undirliggjandi sjúkdóma eđa peir ekki skráđir. Hjá 10 sjúklingum va

ekki hægt að reikna út líkamspyngdarstuðul par sem upplýsingar um hæð eða pyngd vantaði. Hjá fjórum sjúklingum vantað̛i upplýsingar um reykingasögu.

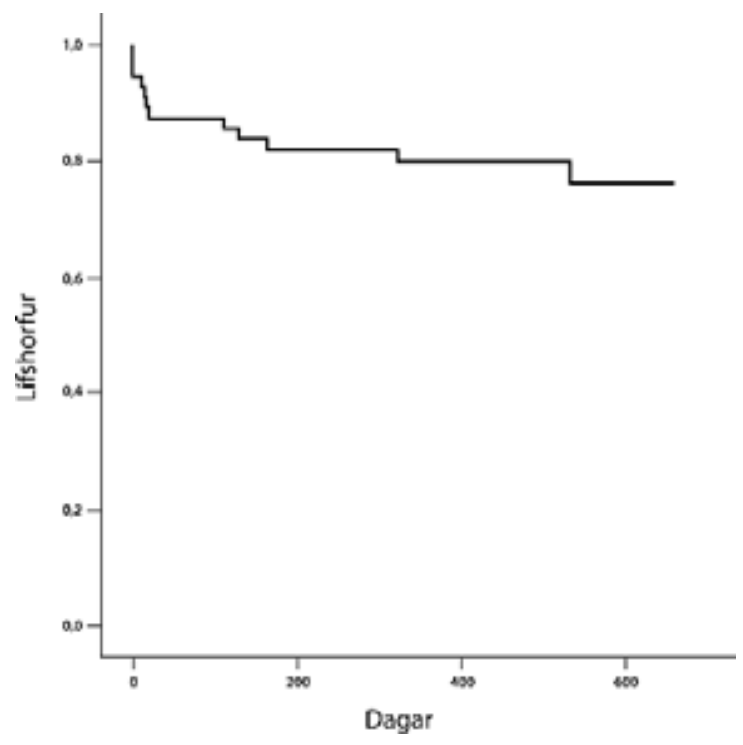

Mynd 2. Kaplan-Meier lifunarkúrfa sem sýnir heildarlifun sjúklinga sem fengu sárasogsmeðferð. Við útreikninga voru teknir með peir 6 sjúklingar sem létust á meðferðartíma.

Sárasuga frá $\mathrm{KCI}^{\circledR}$ og veggsog voru notuð samhliða í fjórum tilvikum (6\%). Tæki frá öðrum framleiðenda var notað í einni meðferð. Ekki reyndist vera marktækur munur á árangri meðferða eftir pví hvaða umbúðir eða tæki voru notuð. Að meðaltali tók sárasogsmeðferð 25 daga (bil 1-203 dagar) og voru 54\% sjúklinganna skemur en 15 daga í meðferð.

Oftast var skipt um umbúðir annan til priðja hvern dag, eða í 80\% meðferða, daglega hjá 6\% og sjaldnar en priðja hvern dag í $9 \%$ tilvika. Upplýsingar um fjölda sáraskiptinga vantaði í premur meðferðum (5\%).

Af 59 meðferðum greru 40 sár að fullu, eða í $68 \%$ tilvika, en gróandi reyndist ófullkominn í hinum 19 meðferðunum (32\%). Í töflu III má sjá árangur sárasogsmeðferðar eftir pví hvaða ábendingar voru fyrir meðferðinni. Alls greru 69\% sýktra sára, 59\% sára pegar verið var að örva gróanda og öll sár par sem sárasogsmeðferð var notuð til að halda holrýmum opnum. Munur á milli pessara hópa var pó ekki marktækur $(\mathrm{p}=0,15)$. Í töflu IV er samanburður á sjúklingum sem höfðu sár sem greru með sárasogsmeðferð og peirra par sem gróandi var ófullnægjandi. Gróandi var sambærilegur fyrir bæði kyn en sjúklingar með fullkominn gróanda voru 10 árum yngri að meðaltali $(\mathrm{p}=0,04)$ og voru marktækt sjaldnar með sykursýki, eða í 25\% tilfella borið saman við 58\% (p=0,02). Ekki reyndist munur á milli hópa hvað varðar líkamspyngdarstuðul, sögu um reykingar né útæðasjúkdóma. Sjúklingar með mænuskaða, bláæðasjúkdóma eða sem fengið höfðu stera eða geislameðferð reyndust of fáir til að hægt væri að leggja mat á árangur meðferðar.

Fylgikvillar sem raktir voru til sárasogsmeðferðar voru skráðir í 19 meðferðum og voru verkir algengastir, eða í 12\% tilfella. Næst á eftir komu húðvandamál (11\%) en blæðing greindist í einni meðferð og aðrir fylgikvillar í premur meðferðum. Ekki reyndist fylgni milli árangurs sárasogsmeðferðar og tíðni fylgikvilla.

Sex sjúklingar létust meðan á sárasogsmeðferð stóð, allir vegna undirliggjandi sjúkdóma, oftast fjölkerfabilunar eða blæðinga, en enginn vegna fylgikvilla meðferðarinnar. Af 50 sjúklingum sem útskrifuðust höfðu 6 til viðbótar látist pann 1. nóvember 2009. Á 
mynd 2 er sýnd heildarlifun (Kaplan-Meier) pessara sjúklinga eftir að meðferð lauk en hún var 80\% eftir eitt ár.

\section{Umræða}

Fullur gróandi náðist með sárasogsmeðferð í rúmlega tveimur priðju tilfella í pessari rannsókn. Petta verður að teljast góður árangur en samkvæmt erlendum rannsóknum næst gróandi í 29-39\% sára með hefðbundinni sárameðferð. ${ }^{5,13}$ Í flestum rannsóknum hefur árangur sárasogsmeðferðar verið betri en við hefðbundna sárameðferð. 5, 6, 13-15 Styrkur pessarar rannsóknar er að hún náði til heillar pjóðar á 12 mánaða tímabili, bæði innan og utan sjúkrahúsa. Slík rannsókn hefur ekki verið gerð áður og pví er samanburður við aðrar rannsóknir erfiður. Auk pess var litið á öll sár, óháð orsök, en í öđrum rannsóknum er algengara að einblínt sé á ákveðna tegund sára, til dæmis sykursýkissár. ${ }^{5,13}$ Petta skiptir máli par sem árangur sárasogsmeðferðar er misgóður eftir tegund sára, og er yfirleitt bestur fyrir langvinn sár. ${ }^{6,8,17}$

Algengasta ábending fyrir sársogsmeðferð voru sýkt skurðsár (28\%). Af skurðsýkingum voru sýkingar í bringubeini eftir opnar hjartaaðgerðir algengastar en fjöldi rannsókna hefur sýnt góðan árangur sárasogs við meðferð slíkra sýkinga.2, ${ }^{12}$ Næst algengasta ábendingin voru langvinn sár, eða í 20\% tilfella, og greru tæplega $60 \%$ peirra að fullu.

Líkt og fyrir hefðbundna sárameðferð er meðferð með sárasogi tímafrek. Meðaltími sem tók sár að gróa var næstum 25 dagar, en helmingur sára voru gróin innan tveggja vikna, sem pykir frekar hátt hlutfall. ${ }^{8}$ Í 80\% tilfella var skipt á sárunum annan til priðja hvern dag en daglega í 6\% tilvika. Fyrir sýkta bringubeinsskurði liðu pó allt að 5 dagar á milli skiptinga. Petta er í samræmi við erlendar rannsóknir en pessar sáraskiptingar parf yfirleitt að gera í svæfingu á skurðstofu. ${ }^{12}$ Við langvinn sár var framkvæmdin hins vegar auðveldari og yfirleitt skipt á umbúðum á sjúkrastofu. Oftast var notast við svampumbúðir, óháð deild. Erlendis hafa grisjur sums staðar náð útbreiðslu án pess að sýnt hafi verið fram á betri árangur með notkun peirra. ${ }^{4}$

Reynt var að leggja mat á pætti sem ýta undir eða tefja fyrir að sár grói við sárasogsmeðferð. Í einpáttagreiningu reyndust einungis sykursýki og hár aldur hefta gróningu sára í meðferðinni. Sjúklingarnir voru pað fáir að ekki greindist marktækur munur á fleiri áhættupáttum, til dæmis reyndust kyn, hár líkamspyngdarstuðull, sterameðferð og saga um útæðasjúkdóma ekki hafa marktækt forspárgildi um gróanda. Aðrar rannsóknir hafa hins vegar sýnt að sárasogsmeðferð gagnast sérstaklega sjúklingum með undirliggjandi sjúkdóma eins og sykursýki og kransæðasjúkdóma. ${ }^{6}$

Ekki var litið sérstaklega á kostnað í pessari rannsókn en pað hefur verið gert í fjölda annarra rannsókna. ${ }^{6,8,16,17}$ Ljóst er að sárasogsmeðferð er dýr meðferð, bæði tækjabúnaður og umbúðir. Samanburðarrannsóknir benda til pess að sárasogsmeðferð sé síst dýrari en hefðbundin sárameðferð. Skýringin er styttri legutími vegna pess að sár gróa hraðar, sem vegur upp á móti auknum kostnaði við umbúðir. Auk pess hlýst vinnusparnaður af færri sáraskiptingum. ${ }^{6,8,16,17}$ Á næstu árum er líklegt að fleiri fyrirtæki komi með tækjabúnað á markað til sárasogsmeðferðar, sem lækkar vonandi kostnað við meðferðina.

Sárasogsmeðferð var oftast veitt á stofnunum, eða í 85\% tilvika. Með smærri og færanlegri sárasogstækjum gæti meðferð orðið al- gengari utan sjúkrahúsa, til dæmis á göngudeildum og í tengslum við heimahjúkrun. Erlendis hefur verið sýnt fram á að kostnaður er allt að helmingi lægri sé meðferðin veitt utan sjúkrahúsa. ${ }^{16}$

Fylgikvillar sem tengdust meðferðinni voru fæstir alvarlegir og voru verkir (12\%) og húðvandamál (11\%) algengust. Æskilegt er að gefa verkjalyf fyrir sáraskiptingar og beita frekar samfelldu sogi en sogi með hléum. ${ }^{18}$ Einnig er hægt að setja vaselín- eða sílíkongrisjur undir sárasogsumbúðirnar svo auðveldara sé að losa pær úr sárinu við sáraskiptingar. ${ }^{18}$ Húðvandamál voru oftast rakin til pess að sárin soðnuðu undan umbúðum. Með pví nota kökur í kringum sárin má verja sárbarmana en einnig er mikilvægt að sníða umbúðir pannig að pær „skríði“ ekki upp á sárbarma og erti pá. ${ }^{1}$

Sex sjúklingar létust meðan á meðferð stóð. Ekki var hægt að tengja dauðsfall neins peirra við fylgikvilla sárasogsmeðferðar, heldur til undirliggjandi sjúkdóma eins og fjölkerfabilunar og innvortis blæðinga. Alvarlegir fylgikvillar sem tengdust meðferðinni komu heldur ekki fyrir. Í erlendum rannsóknum hefur rofi á hjarta- og kviðarholslíffærum verið lýst ${ }^{10,19}$ en rof á líffærum verður oftast pegar skipt er um umbúðir eða pegar beitt er of kröftugu sogi. ${ }^{19}$ Ekki er mælt með notkun veggsogs pví erfitt er að stýra soginu, enda er pað ekki gert fyrir sárasogsmeðferð. ${ }^{9}$ Notast var við veggsog í 13 meðferðum og í fjórum tilfellum til viðbótar ásamt sárasogstæki. Samtals var veggsog pví notað í rúmlega fjórðungi meðferða sem verður að teljast hátt hlutfall. Ástæðan var oftast sú að sárasogstæki voru ekki tiltæk pegar á purfti að halda en pegar rannsóknin fór fram voru aðeins til 5 sárasogstæki á Landspítala og prjú á Sjúkrahúsinu á Akureyri.

Rannsóknin var afturskyggn sem er takmarkandi páttur, sérstaklega pegar kemur að mati á gróanda, fylgikvillum og skráningu ábendinga. Upplýsingar voru aðallega fengnar úr sjúkraskrám og framvinduskýrslum hjúkrunarfræðinga en pær eru ekki jafn nákvæmar og framskyggn skráning. Reyndar kom í ljós við rannsóknina að skráning sárasogsmeðferðar er víða gloppótt, sérstaklega á sumum deildum Landspítala. Mikilvægt er pví að bæta skráningu sárasogsmeðferðar og samræma skráningu milli lækna og hjúkrunarfræðinga, til dæmis með pví að koma á fót sameiginlegum sáragagnagrunni.

Niðurstaða pessarar rannsóknar sýnir að sárasogsmeðferð er töluvert beitt á Íslandi, sérstaklega við meðhöndlun sýktra skurðsára og langvinnra sára. Í tveimur af hverjum premur tilfellum greru sár að fullu, og náðist fullur gróandi innan tveggja vikna í helmingi meðferða. Petta verður að teljast góður árangur borið saman við hefðbundna sárameðferð. Alvarlegir fylgikvillar sem rekja má til meðferðarinnar eru fátíðir og enginn sjúklingur lést vegna sárasogsmeðferðar. Bestur árangur náðist hjá yngri sjúklingum og peim sem ekki höfðu fengið sykursýki.

\section{Pakkir}

Pakkir fá Gunnhildur Jóhannsdóttir og Ólöf Á. Sigurðardóttir skrifstofustjórar á skurðlækningasviði fyrir aðstoð við leit að sjúkraskrám, Ingibjörg Richter kerfisfræðingur á upplýsingatæknisviði fyrir aðstoð við gagnasöfnun, Guðný Bergpóra Tryggvadóttir rannsóknarsérfræðingur á hjúkrunardeild fyrir tölfræðilega aðstoð og Gísli Laxdal Sturlaugsson fyrir yfirlestur. Pessi rannsókn var styrkt af Samtökum um sárameðferð (SUMS) og Félagi íslenskra hjúkrunarfræðinga. 


\section{Heimildir}

1. Argenta LC, Morykwas MJ. Vacuum-assisted closure: a new method for wound control and treatment: clinical experience. Ann Plast Surg 1997; 38: 563-76.

2. Malmsjö $M$, Ingemansson $R$, Sjögren J. Mechanism governing the effects of vacuum-assisted closure in cardiac surgery. Plast Reconstr Surg 2007; 120: 1266-75.

3. Mouës CM, Vos MC, van den Bemd GJ, Stijnen T, Hovius SE. Bacterial load in relation to vacuum-assisted closure wound therapy: a prospective randomized trial. Wound Repair Regen 2004; 12: 11-7.

4. Borgquist $\mathrm{O}$, Gustafsson $\mathrm{L}$, Ingemansson R, Malmsjö M. Micro- and macromechanical effects on the wound bed of negative pressure wound therapy using gauze and foam. Ann Plast Surg 2010; 64: 789-93.

5. Blume PA, Walters J, Payne W, Ayala J, Lantis J. Comparison of negative pressure wound therapy using vacuum-assisted closure with advanced moist wound therapy in the treatment of diabetic foot ulcers. Diabetes Care 2008; 31: 631-6.

6. Braakenburg A, Obdeijn MC, Feitz R, van Rooij IA, van Griethuysen AJ, Klinkenbijl JH. The clinical efficacy and cost effectiveness of the vacuum-assisted closure technique in the management of acute and chronic wounds: a randomized controlled trial. Plast Reconstr Surg 2006; 118: 390-7.

7. Svensson S, Monsen C, Kölbel T, Acosta S. Predictor for outcome after vacuum assisted closure therapy of peri-vascular surgical site infection of the groin. Eur J Vasc Endovasc Surg 2007; 36: 84-9.
8. Vuerstaek JD, Vainas T, Wuite J, Nelemans P, Neumann $\mathrm{MH}$, Veraart JC. State-of-the-art treatment of chronic leg ulcers: A randomized controlled trial comparing vacuum-assisted closure (V.A.C.) with modern wound dressing. J Vasc Surg 2006; 44: 1029-37.

9. Argenta LC, Morykwas MJ, Marks MW, DeFranzo AJ Molnar JA, David LR. Vacuum-assisted closure: State of clinic art. Plast Reconst Surg 2006; 117: 127S-142S.

10. Sjögren J, Gustafsson R, Nilsson J, Lindstedt S, Nozohoor $S$, Ingemansson R. Negative-pressure wound therapy following cardiac surgery: bleeding complications and 30-days mortality in 176 patients with deep sternal wound infection. Interact Cardiovasc Thorac Surg 2011; 12: 117-20.

11. Lambert KV, Hayes P, McCarthy M. Vacuum assisted closure: A review of development and current applications. Eur J Vasc Endovasc Surg 2005; 29: 219-26.

12. Sjögren $\mathrm{J}$, Malmsjö $\mathrm{M}$, Gustafsson R, Ingemansson $\mathrm{R}$ Poststernotomy mediastinitis: a review of conventional surgical treatments, vacuum-assisted closure therapy and presentation of the Lund University Hospital mediastinitis algorithm. Eur J Cardiothorac Surg 2006; 30: 898-905.

13. Armstrong DG, Lavery LA, Diabetic Foot Study Consortium. Negative pressure wound therapy after partial diabetic foot amputation: a multicentre, randomised controlled trial. Lancet 2005; 366: 1704-10.

14. Moisidis E, Heath T, Boorer C, Ho K, Deva AK. A prospective, blinded, randomized, controlled clinical trial of topical negative pressure use in skin grafting. Plast Reconstr Surg 2004; 114: 917-22.
15. Llanos S, Danilla S, Barraza C, Armijo E, Piñeros JL, Quintas $\mathrm{M}$, et al. Effectiveness of negative pressure closure in the intergration of split thickness skin grafts: a randomized, double-masked, controlled trial. Ann Surg 2006; 244: 700-5.

16. Apelqvist $\mathrm{J}$, Armstrong DG, Lavery LA, Boulton AJ. Resource utilization and economic costs of care based on a randomized trial of vacuum-assisted closure therapy in the treatment of diabetic foot wounds. Am J Surg 2008; 195: 782-8.

17. Mouës CM, van den Bemd GJ, Meerding WJ, Hovius SE. An economic evaluation of the use of TNP on full-thickness wounds. J Wound Care 2005; 5: 224-7.

18. Attinger CE, Janis JE, Steinberg J, Schwartz J, Al-Attar A, Couch K. Clinical approach to wounds: débridement and wound bed preparation including the use of dressings and wound-healing adjuvants. Plast Reconstr Surg 2006; 117: 72S-109S.

19. Petzina R, Malmsjö M, Stamm C, Hetzer R. Majo complications during negative pressure wound therapy in poststernotomy mediastinitis after cardiac surgery. J Thorac Cardiovasc Surg 2010; 140: 1133-6.

\section{ENGLISH SUMMARY}

\section{Negative pressure wound therapy in Iceland - indication and outcome}

Gudmundsdottir $\mathrm{I}^{1}$, Steingrimsson $\mathrm{S}^{2}$, Gudbjartsson $\mathrm{T}^{2,3}$

Introduction: Negative pressure wound therapy (NPWT) is a recent therapeutic option in wound healing, where a vacuum source is used to create sub-atmospheric pressure in the wound bed with airtight dressings. The aims were to study the indications for the use of NPWT in a whole country and evaluate the outcome of treatment.

Material and methods: This was a retrospective study that included all patients that were treated with NPWT in Iceland between January and December 2008. Information on indication, duration and outcome of treatment was collected from patient charts. Factors that are known to affect wound healing, such as diabetes, smoking and age, were also registered.

Results: During the 12 month study period a total of 65 NPWT-treatments were given to 56 patients; 35 (63\%) males and 21 (37\%) females, with an average age of $62 \mathrm{yrs}$ (range; 8 - 93). The indications for treatment were: wound infection (40\%), promotion of wound healing (42\%) and keeping cavities open (19\%). The lower limbs (26\%) and chest area (25\%) were the most common sites for treatment. Six patients died during the treatment period, none of them due to complications related to NPWT, and these patients were excluded from analysis of wound healing. In the other 59 treatments, 40 wounds (68\%) healed successfully, but healing was incomplete in 19. Treatment related complications were recorded in 19 (32\%) cases; wound pain (12\%) and skin problems (11\%) being the most common ones.

Conclusion: NPWT has been used considerably in Iceland, especially for infected surgical wounds and chronic wounds. In two thirds of cases a complete wound healing was achieved, which must be regarded as a favorable outcome.

Key words: Negative pressure wound therapy (NPWT), wound infectons, indications, outcome, healing rate.

Correspondence: Tómas Guðbjartsson, tomasgud@landspitali.is

${ }^{1}$ Department of Vascular surgery, ${ }^{2}$ Cardiothoracic surgery, Landspitali University Hospital, ${ }^{3}$ Faculty of Medicine, University of Iceland. 